\title{
Effect of Modified Atmosphere Packaging on the Refrigerated Storage of Mantı
}

\author{
Sinan Uzunlu*, Işıll Var \\ Food Engineering Department, Agricultural Faculty, Çukurova University, 01330 Adana, Turkey \\ A R T I C L E I N F O \\ Article history: \\ Received 11 September 2015 \\ Accepted 10 December 2015 \\ Available online, ISSN: 2148-127X \\ Keywords: \\ Mantı \\ Modified atmosphere packaging \\ Traditional foods \\ A B S T R A C T \\ Mant1, the traditional Turkish food, was subjected to modified atmosphere packaging \\ (MAP) compositions of MAP $1\left(80 \% \mathrm{CO}_{2}+20 \% \mathrm{~N}_{2}\right)$, MAP $2\left(40 \% \mathrm{CO}_{2}+60 \% \mathrm{~N}_{2}\right)$, \\ MAP $3\left(60 \% \mathrm{CO}_{2}+40 \% \mathrm{~N}_{2}\right)$ and control (packaged under atmospheric composition) to \\ extend its refrigerated storage at $4{ }^{\circ} \mathrm{C}$. The physical, chemical and sensorial qualities of \\ each package were assessed by analysing headspace gas composition, $\mathrm{pH}$, water activity, \\ 2-thiobarbituric acid (TBA), dry matter, lipid content and a sensory analysis of both \\ cooked and raw mant samples. The compositions of MAP samples (MAP 1, MAP 2 and \\ MAP 3) resulted in the maximum storage time of 126 days versus 20 days in normal \\ atmospheric packaging (control). In conclusion, $60 \% \mathrm{CO}_{2}$ or either $80 \% \mathrm{CO}_{2}$ with $\mathrm{N}_{2}$, as \\ a make-up gas, should be implemented in the mantı process.
}

MAP

Sensory

\section{${ }^{*}$ Corresponding Author:}

E-mail: suzunlu@pau.edu.tr

\section{Introduction}

Mant1, the traditional Turkish food, is commonly consumed as a nutritious product in Turkey. Mant1 stuffing typically consists of specific proportions of minced beef meat, onion, paprika, black pepper and salt. Approximately, one-quarter of the water used for the preparation of dough is added to a mixture of wheat flour and salt during a hand-kneading process. A preheat treatment is applied according to consumer/retailer preferences before cooking. Cooking is generally applied in boiling water for 10-15 minutes, and then it is served with tomato sauce and garlic yoghurt sauce and some dried mint and sumac (Sitti et al., 2009; Öztürk et al., 2009).

When combined with cold storage, MAP provides stable food products for long term storage. In the literature, studies reported effect of MAP gases $\left(\mathrm{CO}_{2}\right.$ and $\mathrm{N}_{2}$ ) in cold storage on the shelf life of raw beef (Ho et al., 2003; Barrera et al., 2007; Gökoğlu et al., 2011; Carola et al., 2013) and ravioli, cannelloni and tortellini, which are similar to mant1 (McGuire et al., 1989; Liggett et al., 1990; Giannuzzi, 1998; Sanguinetti et al., 2011).

Therefore, the current research was performed to determine the refrigerated storage of modified atmosphere packed mant 1 at $4^{\circ} \mathrm{C}$ by measuring physical, chemical and sensory parameters.

\section{Materials and methods}

\section{Mantı Samples}

Wheat flour, minced beef meat, dry onion, black pepper, salt and water were used as the raw materials of mant 1 and purchased from a local market in Antalya (Turkey). Dough was prepared by mixing wheat flour and water at a $2: 1$ ratio $(\mathrm{w} / \mathrm{v})$ to obtain $0.1925 \mathrm{~mm}$ average sheeted dough by using a dough roller manually. The filling was prepared by mixing minced beef, kneaded dry onion $(5 \% \mathrm{w} / \mathrm{w}$ of mant 1$)$, salt $(2 \% \mathrm{w} / \mathrm{w}$ of mant 1$)$ and black pepper $(0.5 \% \mathrm{w} / \mathrm{w}$ of mant 1$)$. Stuffing material was filled to each square of dough $\left(30 \mathrm{~mm}^{2}\right)$ in an equal amount, which averaged 1.275 grams. The heat treatment was performed in an oven (Inoksan, Bursa/Turkey) with a product centre temperature of $60^{\circ} \mathrm{C}$ and treatment time of four minutes. The temperature was monitored by using a manual thermo logger. The product was left to cool at ambient temperature $\left(\sim 20^{\circ} \mathrm{C}\right)$ and immediately transported at $4^{\circ} \mathrm{C}$ within a van for MAP treatments.

\section{MAP Application}

The samples of mantı were packaged under different gas combinations at the plant Antalya Altın Et Entegre Tesisleri, Turkey. Samples were placed in polypropylene trays with a water vapour transmission rate of $\leq 1$ cc/tray/day and trays were sealed with a $25 \mu$ thick polyolefin based film, an oxygen transmission rate of 24 
$\mathrm{cm}^{3} / \mathrm{m}^{2} /$ day/bar and with an $18 \mathrm{~g} / \mathrm{m}^{2} /$ day $\left(38^{\circ} \mathrm{C}, 100 \%\right.$ $\mathrm{RH})$ water vapour transmission rate. MAP was carried out using G. Mondini (Italy) packaging machine. Sealing temperature was $150^{\circ} \mathrm{C}$ and a $2 / 1(\mathrm{v} / \mathrm{w})$ gas volume to mant1 ratio in each pack was applied. Gas mixtures were designed for MAP $1\left(80 \% \mathrm{CO}_{2}+20 \% \mathrm{~N}_{2}\right)$, MAP $2(40 \%$ $\left.\mathrm{CO}_{2}+60 \% \mathrm{~N}_{2}\right)$, MAP $3\left(60 \% \mathrm{CO}_{2}+40 \% \mathrm{~N}_{2}\right)$ and control $\left(78 \% \mathrm{~N}_{2}+20.8 \% \mathrm{O}_{2}\right)$ treatments. Samples from MAP1, MAP 2 and MAP 3 were stored at $4{ }^{\circ} \mathrm{C}, 50-63 \% \mathrm{RH}$ for 126 days. Control samples were stored at $4^{\circ} \mathrm{C}, 50-63 \%$ RH until they reached the spoilage period, then mould mycelia inside the tray was observed. Analyses were performed on days $0,1,3,5$ and 7 and then at seven day intervals up to the day 126 .

\section{Physical, Chemical and Sensory Analysis}

The gas composition of headspace in packages was measured using a digital Oxybaby $M$ (Germany) gas analyser and expressed as $\mathrm{CO}_{2} \%$ and $\mathrm{O}_{2} \%$. The remaining gas was $\mathrm{N}_{2} ; \mathrm{pH}$ of the whole sample (filling and dough) was determined using the Association of Analytical Communities (AOAC) method. 10 grams of sample were homogenised in $90 \mathrm{~mL}$ of distilled water and $\mathrm{pH}$ value were recorded by using $\mathrm{pH}$ meter (P Selecta $\mathrm{pH} 2001$, Spain) averaging 3 measurements. Water activity (aw) of the whole samples was measured using a water activity meter (Novasina, Labmaster model, Switzerland).

10 grams of each whole sample was blended with 50 $\mathrm{mL}$ of distilled water in a Waring blender for 2 minutes for TBARS (thiobarbituric acid reactive substances) analysis. The mixture transferred quantitatively into Kjeldahl tubes by washing with an additional $47.5 \mathrm{~mL}$ of distilled water. $4 \mathrm{~N} 2.5 \mathrm{~mL} \mathrm{HCl}$ was added and distilled up to a $200 \mathrm{~mL}$ final distillate. 5 millilitres of distillate mixed with $5 \mathrm{~mL} 0.02 \mathrm{M}$ TBA reactive using vortex (100 $\mathrm{mL}$ TBA reactive was prepared by $90 \mathrm{~mL}$ glacial acetic acid and $10 \mathrm{~mL}$ distilled water). For blank $5 \mathrm{~mL}$ TBA reactive was mixed with $5 \mathrm{~mL}$ distilled water. Each tube was immersed in boiling water bath for 35 minutes and cooled at tap water for 10 minutes. Optical density was read against the blank at a wavelength of $538 \mathrm{~nm}$ using a spectrophotometer (Shimadzu UV-1700 Pharmaspec, Japan). Data were multiplied by the factor 7.8 to convert the mg of malonaldehyde per 1000 grams of the whole sample (Anonymous, 2009).

The dry matter content of mant samples were determined as follows: 5 grams of each whole samples were grinded and weighed into a constant weight aluminium caps. Thereafter, samples were dried in an oven at $105^{\circ} \mathrm{C}$ for overnight until the samples reached to a constant weight (Cemeroğlu, 2007).

To determine lipid content of the samples 10 grams of whole sample was blended with $200 \mathrm{~mL}$ of chloroform/methanol $(2: 1)$ in a Waring blender for 3 minutes at low speed. Homogenate was filtered through a Whatman Filter No. 1 paper into a $500 \mathrm{~mL}$ separating funnel. Filtrate was re-extracted with $50 \mathrm{~mL}$ of chloroform/methanol (2:1) and again filtered through the same filter paper. Blender and filter paper were rinsed twice with $20 \mathrm{~mL}$ of chloroform/methanol (2:1). A $60 \mathrm{~mL}$ portion of $0.72 \% \mathrm{KCl}$ was added to the solution in the separating funnel and the contents were mixed. After phase separation, lipid layer was separated and another 20 $\mathrm{mL}$ of $0.72 \% \mathrm{KCl}$ was added. The lipid phase after phase separation was filtered through a Whatman No. 1 filter paper with anhydrous $\mathrm{NaSO}_{4}$ into a $200 \mathrm{~mL}$ volumetric flask. From this extract an aliquot of $10 \mathrm{~mL}$ was taken to a flask and solvent evaporated in boiling water. Flask was dried in an oven at $100^{\circ} \mathrm{C}$ for one hour and total lipid content was determined gravimetrically (Baggio et al., 2002).

The water vapour transmission rate of the tray was measured at $38^{\circ} \mathrm{C} / 90 \% \mathrm{RH}$ using the ASTM F-1249 method (Anonymous, 2011). The oxygen transmission rate of the film was measured at $23^{\circ} \mathrm{C}$ according to the ASTM D-3985 method (Anonymous, 2010). Those analyses were performed at TUBITAK MAM (The Scientific and Technological Research Council of Turkey Marmara Research Center), Gebze facilities.

Sensory analysis was performed with nine trained panellists in cooked mantı (samples cooked in boiling water and held for seven minutes when the product centre temperature reached $80^{\circ} \mathrm{C}$ ) scored it in the range of $1-5$ points for appearance, flavour and odour, texture and taste. In raw samples appearance, texture, flavour and odour were evaluated. The panel room was odourless, had a hand washing stand and the lighting and room temperature $\left(20-22^{\circ} \mathrm{C}\right)$ were uniform. Water was provided to panellists after each taste evaluation (Altuğ and Elmac1, 2011).

\section{Statistical Analysis}

Each trial was repeated twice and triplicate samples were tested at each sampling time. Data were subjected to variance analysis in order to determine the effect of gas composition and storage time on each variable. The analysis was performed using analysis of variance (ANOVA) one-way analysis, and statistical package (SPSS 15.0, USA) was used to identify the different groups. The Duncan's post hoc test was applied; significance level was $\mathrm{p}<0.05$. Control group samples were not included in statistical analysis owing to the earlier spoilage record on day $21^{\text {st }}$.

\section{Results and Discussion}

\section{Physical and Chemical Analyses}

There was a decrease in the percentages of carbon dioxide during the cold storage owing to the absorption from the product itself and leakage from the package, while the values for control group samples' were increased to $0.3 \%$ on day $14^{\text {th }}$ and finally to $4.6 \%$ on day $21^{\text {st }}$ (Figure 1). Lactic acid bacteria and Gram (-) bacteria might produce carbon dioxide in headspace during the growth (Limbo et al., 2010). Earlier researches stated that headspace gas composition is not steady during storage owing to the microbial metabolism, gas solubility and film permeability (Jakobsen and Bertelsen, 2002; Simpson et al., 2009; Limbo et al., 2010). These findings are consistent with the result of present study. 


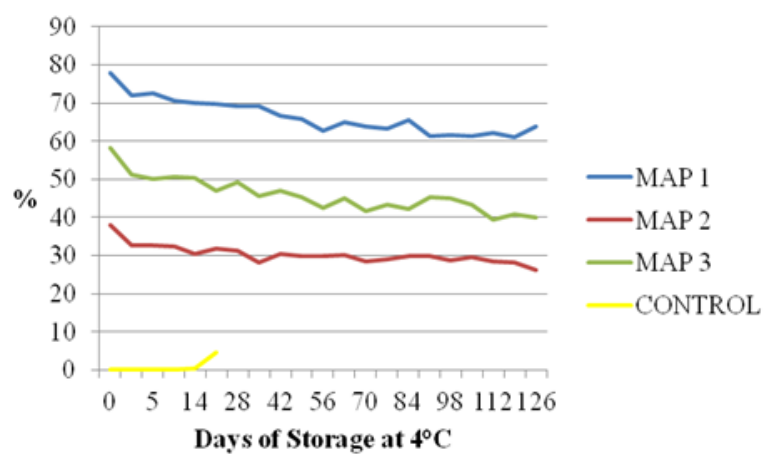

Figure 1. The changes in the percentages of carbondioxide during storage $(\%)$. Legends to Figures: MAP $1\left(80 \% \mathrm{CO}_{2}+20 \% \mathrm{~N}_{2}\right)$, MAP $2\left(40 \% \mathrm{CO}_{2}+60 \%\right.$ $\left.\mathrm{N}_{2}\right)$, MAP $3\left(60 \% \mathrm{CO}_{2}+40 \% \mathrm{~N}_{2}\right)$ and control $\left(78 \% \mathrm{~N}_{2}+\right.$ $20.8 \% \mathrm{O}_{2}$ ) treatments of modified atmosphere packaging (MAP).

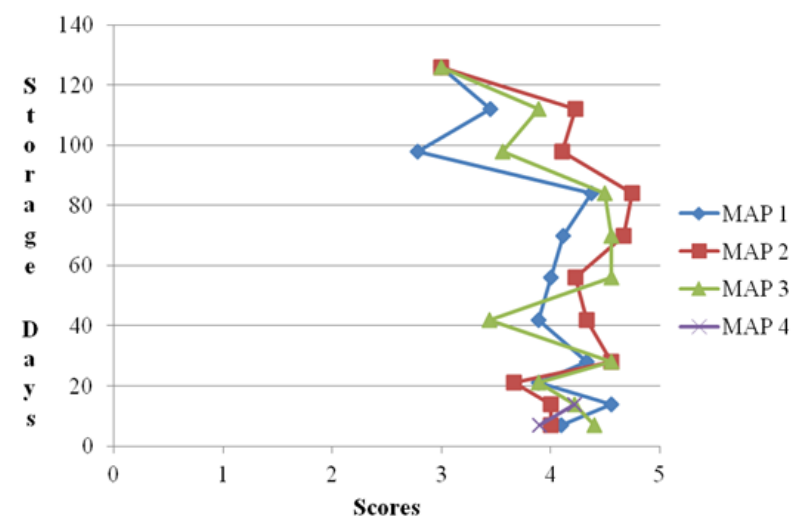

Figure 2 The changes of overall acceptability scores during storage in cooked mantı samples. Legends to Figures: MAP $1\left(80 \% \mathrm{CO}_{2}+20 \% \mathrm{~N}_{2}\right)$, MAP $2\left(40 \% \mathrm{CO}_{2}\right.$ $\left.+60 \% \mathrm{~N}_{2}\right)$, MAP $3\left(60 \% \mathrm{CO}_{2}+40 \% \mathrm{~N}_{2}\right)$ and control $\left(78 \% \mathrm{~N}_{2}+20.8 \% \mathrm{O}_{2}\right)$ treatments of modified atmosphere packaging (MAP).

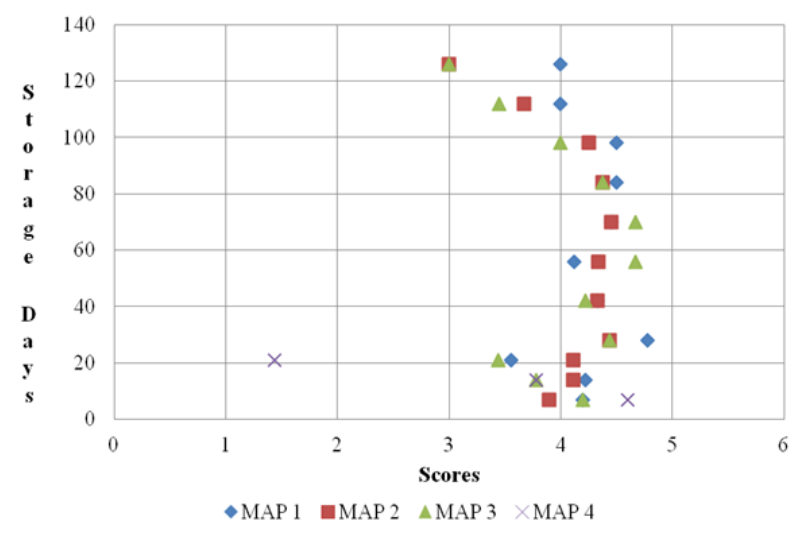

Figure 3 The changes of overall acceptability scores during storage in raw mant1 samples. Legends to Figures: MAP $1\left(80 \% \mathrm{CO}_{2}+20 \% \mathrm{~N}_{2}\right)$, MAP $2\left(40 \% \mathrm{CO}_{2}+60 \%\right.$ $\left.\mathrm{N}_{2}\right)$, MAP $3\left(60 \% \mathrm{CO}_{2}+40 \% \mathrm{~N}_{2}\right)$ and control $\left(78 \% \mathrm{~N}_{2}+\right.$ $20.8 \% \mathrm{O}_{2}$ ) treatments of modified atmosphere packaging (MAP).
The levels of oxygen were found steady during the storage period (Figure 1), which was below 1.6\%. The level of oxygen in control group samples' was decreased from $20.8 \%$ to $13.85 \%$ on day 21 . It might be resulted from the growth of microorganisms (data not shown). Similar results were obtained at earlier researches, for bread (Degirmencioglu et al., 2011), and for beef (Ercolini et al., 2006).

Water activity $\left(\mathrm{a}_{\mathrm{w}}\right)$ values were found in the range of 0.876 and 0.904 . There were no significant difference $(\mathrm{P}<0.05)$ during storage period and among the MAP conditions (data not shown). Spoilage related with mould in bakery products might be prevented by decreasing $\mathrm{a}_{\mathrm{w}}$ to 0.80 and using a $70 \% \mathrm{CO}_{2}$ in packaging (Giorni et al., 2008).

In the case of TBA values, there were no significant difference $(\mathrm{P}<0.05)$ among the samples during the storage period, until $98^{\text {th }}$ day (Table 1). TBA values were higher in control samples than MAP packaged samples during the 21 day of storage (Table 1). It is well known that oxygen is the key element when forming TBA (Campo et al., 2006; Jongberg et al., 2011). Both using reduced oxygen and increased nitrogen levels in packaging are required to obtain lower TBA values (Berruga et al., 2005; Zakrys et al., 2008; Zakrys et al., 2009; Limbo et al., 2010; Zakrys-Waliwander et al., 2010). Literature values are consistent with the findings of current study. Using oxygen free MAP packages resulted in lower TBA values, because of the low lipid content of the meat. Lipid content of the samples remained at below 4\% (data not shown), which is in the range of Turkish Standards quality index (Anonymous, 2003). A study reported that high lipid content of the meat might be one of the several reasons of high TBA value in mantı samples (Yücetepe, 2011). So, this implies the findings of current study.

The $\mathrm{pH}$ values of the samples were significantly $(\mathrm{P}<0.05)$ different on the last two storage days, which are $119^{\text {th }}$ and $126^{\text {th }}$ (data not shown). The biggest decrease was observed (from 6.52 to 6.04) on MAP 1 condition, which pertains to the higher carbondioxide content. The others (MAP 2 and MAP 3) were slightly decreased (data not shown); the values for air packed samples were increased from 6.54 to 6.95 on day $21^{\text {st }}$. The finding for increased value of air packed sample was in accordance with a report (Argyri et al., 2011).

Dry matter of the samples were significantly $(\mathrm{P}<0.05)$ different among the MAP conditions on day $98^{\text {th }}, 119^{\text {th }}$, and $126^{\text {th }}$ days during the storage period (data not shown). There were slight decreases from the initial values at the end of the storage period.

Finally, the packaging materials were analysed for confirmation of delivery firm. The water vapour transmission rate of the tray was measured as 0.629 $\mathrm{g} / \mathrm{m}^{2} /$ day. The oxygen transmission rate of the film was found to be $16.5 \mathrm{ml} / \mathrm{m}^{2} /$ day. It is stated that using films below $2 \mathrm{ml} / \mathrm{m}^{2} / 24 \mathrm{~h}$ oxygen permeability rate might extend shelf life of foods about $10-15 \%$ (Singh et al., 2011). 


\section{Sensory Analyses}

Scores for appearance, flavour, odour, texture and taste of cooked mantı samples showed similar trends in terms of decreasing sensorial quality up to a final day of 126. The variability in the results of a proximate analysis, such as lipid and $\mathrm{pH}$ of the samples, did not negatively affect sensory perception. Scores of raw mantı samples showed similar decreasing trend during refrigerated storage. It can be concluded that in terms of overall quality, MAP 2 samples were the most preferred for cooked samples during the storage period (Figure 2) while the highest scores were obtained for MAP 1 raw samples (Figure 3).

In conclusion, MAP could extend the refrigerated storage of raw, fresh mantı up to six times compared to air packaging. The result of present study showed that the best preservation for raw fresh mant 1 was in MAP $1(80 \%$ $\mathrm{CO}_{2}+20 \% \mathrm{~N}_{2}$ ) gas composition, which ensured acceptable sensory, physical and chemical analyses until the end of storage period of 126 days.

Table 1 The changes in TBA (thiobarbituric acid) values of packed mant1 samples during storage at $4^{\circ} \mathrm{C}$.

\begin{tabular}{|c|c|c|c|c|}
\hline Storage days & $\overline{\text { MAP } 1}$ & $\overline{\text { MAP } 2}$ & MAP 3 & MAP 4 \\
\hline 7 & $0^{\mathrm{ax}}$ & $0.1092^{b x}$ & $0.0858^{b x}$ & 0.2574 \\
\hline 14 & $0.1638^{x}$ & $0.1248^{x}$ & $0.1404^{\mathrm{x}}$ & 0.3042 \\
\hline 21 & $0.2366^{x}$ & $0.156^{\mathrm{x}}$ & $0.1872^{\mathrm{x}}$ & 0.3666 \\
\hline 28 & $0.3016^{a b x}$ & $0.2106^{\mathrm{abx}}$ & $0.1456^{b x}$ & $*$ \\
\hline 42 & $0.3224^{\text {ay }}$ & $0.2548^{\text {by }}$ & $0.3588^{\text {ay }}$ & * \\
\hline 56 & $0.3406^{\mathrm{y}}$ & $0.3564^{\mathrm{y}}$ & $0.4022^{\mathrm{y}}$ & * \\
\hline 70 & $0.4235^{\mathrm{y}}$ & $0.4602^{y}$ & $0.4472^{\mathrm{y}}$ & $*$ \\
\hline 84 & 0.351 ay & $0.3354^{\text {ay }}$ & 0.5772 by & * \\
\hline 98 & $0.195^{\mathrm{az}}$ & $0.2522^{\mathrm{bz}}$ & $0.2496^{b z}$ & $*$ \\
\hline 112 & $0.5278^{\text {aq }}$ & $0.39^{\mathrm{bq}}$ & $0.4945^{\mathrm{aq}}$ & * \\
\hline 126 & $0.507^{\text {av }}$ & $0.2886^{b v}$ & $0.5304^{\text {av }}$ & * \\
\hline
\end{tabular}

Spoiled mantı sample. Data in the same column bearing different superscript letters (x,y,z,q,v) are significantly different ( $<<0,05)$. Data in the same row bearing different superscript letters $(a, b, c)$ are significantly different $(\mathrm{p}<0,05)$. MAP $1\left(80 \% \mathrm{CO}_{2}+20 \% \mathrm{~N}_{2}\right)$, MAP $2\left(40 \% \mathrm{CO}_{2}+60 \% \mathrm{~N}_{2}\right)$, MAP $3\left(60 \% \mathrm{CO}_{2}+40 \% \mathrm{~N}_{2}\right)$ and control $\left(78 \% \mathrm{~N}_{2}+20.8 \% \mathrm{O}_{2}\right)$ treatments of modified atmosphere packaging (MAP)

\section{Acknowledgements}

This research was funded by Çukurova University (Project Nr: ZF2010D6).

\section{References}

Altuğ OT, Elmacı Y. 2011.Gıdalarda Duyusal Değerlendirme (in Turkish), İzmir, Turkey.

Anonymous. 2001. Official Methods of Analysis of AOAC International, 17th Edtn. $2^{\text {nd }}$ revision. Association Official Analytical Chemists, Arlington, VA.

Anonymous. 2003. Türk Standard1. Mant1-Dondurulmuş. Türk Standartları Enstitüsü, Necatibey cad. No 112 Bakanlıklar/Ankara, Turkey.

Anonymous. 2009. 2-Thiobarbituric Acid Value Direct Method, AOCS OfficialMethodCd 19-90.

Anonymous. 2010. "ASTM Standard D 3985-05 Standard.Standard test method for oxygen gas transmission rate through plastic film and sheeting using a coulometric sensor". ASTM International, West Conshohocken, PA, 2010, DOI: 10.1520/D3985-05R10E01, available at: http://www.astm.org. (Accessed 11 December 2011)

Anonymous. 2011. "ASTM Standard F 1249-06 Standard. Standard test method for water vapor transmission rate through plastic film and sheeting using a modulated infrared sensor". ASTM International, West Conshohocken, PA, 2011, DOI: 10.1520/F1249-06R11, available at: http://www.astm.org. (Accessed 11 December 2011)

Argyri AA, Doulgeraki AI, Blana VA, Panagou EZ, Nychas GJE. 2011. Potential of a simple HPLC-based approach for the identification of the spoilage status of minced beef stored at various temperatures and packaging systems. Int $\mathrm{J}$ Food Microbiol, 150: 25-33.doi: 10.1016/j.ijfoodmicro.2011.07.010
Baggio SR, Vicente E, Bragagnolo N. 2002. Cholesterol oxides, cholesterol, total lipid, and fatty acid composition in Turkey meat. J Agric Food Chem, 50: 5981-5986.doi: $10.1021 / \mathrm{jf020025c}$

Barrera O, Rodríguez-Calleja JM, Santos JA, Otero A, GarcíaLópez ML. 2007. Effect of different storage conditions on E.coli $\mathrm{O} 157: \mathrm{H} 7$ and the indigenous bacterial microflora on lamb meat. Int J Food Microbiol, 115: 244-251. doi:10.1016/j.ijfoodmicro.2006.10.053

Berruga MI, Vergara H, Linares MB. 2005. Control of Microbial Growth and Rancidity in Rabbit Carcasses by Modified Atmosphere Packaging. J Sci Food Agric, 85: 1987-1991.doi: $10.1002 /$ jsfa. 2183

Campo MM, Nute GR, Hughes SI, Enser M, Wood JD, Richardson RI. 2006. Flavour perception of oxidation in beef. Meat Sci 72: 303-311.doi:10.1016/j.meatsci.2005.07.015

Carola G, Helen JH, Jutta R, Joseph SG. 2013. Fresh Meat Packaging: Consumer Acceptance of Modified Atmosphere Packaging including Carbon Monoxide. J Food Protect, 1: 99107. doi: http://dx.doi.org/10.4315/0362-028X.JFP-12-045

Cemeroğlu B. 2007.Gıda Analizleri, Ankara, Turkey.

Degirmencioglu N, Göcmen D, Inkaya AN, Aydın E, Güldas M, Gönenc S. 2011. Influence of Modified Atmosphere Packaging and Potassium Sorbate on Microbiological Characteristics of SlicedBread. J Food Sci Technol, 48: 236-241.doi: 10.1007/s13197-010-0156-4

Ercolini D, Russo F, Torrieri E, Masi P, Villani F. 2006. Changes in the spoilage-related microbiata of beef during refrigerated storage under different packaging conditions. ApplEnvMicrobiol, 72: 4663-4771. doi: 10.1128/AEM.0046806

Giannuzzi L. 1998.Shelf-Life of fresh filled pasta. Hazard analysis and critical control points of the manufacturing process and household practices. J Food Proces Preserv, 29: 449-461.doi: 10.1111/j.1745-4549.1998.tb00362.x 
Giorni P, Battilani P, Pietri A, Magan N. 2008. Effect of $\mathrm{a}_{\mathrm{w}}$ and $\mathrm{CO}_{2}$ level on Aspergillusflavusgrowth and aflatoxin production in high moisture maize post-harvest. Int J Food Microbiol, 122: 109-113.doi:10.1016/j.ijfoodmicro.2007.11.051

Gökoğlu N,Yerlikaya P, Uran H, Topuz OK. 2011. Effects of packaging atmospheres on the quality and shelf life of beef steaks. J Fac Vet Med Univ Kafkas, 17: 435-439.doi: $10.9775 / \mathrm{kvfd} .2010 .3712$

Ho CP, Huang NY, McMillin KW.2003. Microflora and colour of ground beef in gas exchange modified atmosphere packaging with abusive display temperatures. J Food Sci, 68: 17711776.doi: 10.1111/j.1365-2621.2003.tb12327.x

Jakobsen M, Bertelsen G. 2002.The Use of $\mathrm{CO}_{2}$ in Packaging of Fresh Red Meatsand Its Effect on Chemical Quality Changes In the Meat: A Review. J Muscle Foods, 13: 143-168.doi: 10.1111/j.1745-4573.2002.tb00326.x

Jongberg S, Skov SH, Tørngren MA, Skibsted LH, Lund MN. 2011. Effect of White Grape Extract and Modified Atmosphere Packaging on Lipidand Protein Oxidation in Chill Stored Beef Patties. Food Chem, 128: 276-283. doi:10.1016/j.foodchem. 2011.03.015

Limbo S, Torri L, Sinelli N, Franzetti L, Casiraghi E. 2010. Evaluation and predictive modeling of shelf life of minced beef stored in high-oxygen modified atmosphere packaging at different temperatures. Meat Sci, 84: 129136.doi:10.1016/j.meatsci.2009.08.035

Liggett L, McGuire M, Palmer M, DeGiacomo R. 1990. Method for preparing and preserving filled pasta products. United States Patent, Patent Number: 4,898,744, Date of Patent: Feb. 6, 1990.

McGuire M, Digiacomo R, Palmer M, Liggett L. 1989.Method for preparing and preserving fresh pasta. United States Patent, Patent Number: 4,876,104, Date of Patent: Oct. 24, 1989.

Öztürk I, Sağdıç O, Yetim H, Karaman S, Kayacıer A. 2009. Kayseri piyasasında satılan mantıların bazı mikrobiyolojik özellikleri. Proceedings of the II. Geleneksel Gidalar Sempozyumu, Van, Turkey, 2009, 862-865.
Sanguinetti AM, Del Caro A, Mangia NP, Secchi N, Catzeddu P, Piga A. 2011. Quality changes of fresh filled pasta during storage: Influence of modified atmosphere packaging on microbial growth and sensory properties. Food Sci Tech Int, 17: 23-29.doi: $10.1177 / 1082013210368742$

Simpson R, Acevedo C, Almonacid S. 2009. Mass transfer of $\mathrm{CO}_{2}$ in MAP systems: advances for non-respiring foods. J Food Eng, 92: 233-239.doi:10.1016/j.jfoodeng.2008.10.035

Singh P, Wani AA, Säengerlaub S, Langowski HC. 2011. Understanding critical factors for the quality and shelf-life of MAP fresh meat: a review. Crit Rev Food Sci Nutr, 51: 146177.doi:10.3923/ajft.2011.202.214

Sitti S, Hayta M, Yetim H. 2009. Kayseri mantısı: Hazırlanışı ve kalite nitelikleri. Proceedings of the II. Geleneksel Gidalar Sempozyumu, Van, Turkey, 2009, 208-211.

Yücetepe A. 2011. Modifiye atmosferde ambalajlamanın etli mantının kalitesi üzerine etkileri. MsC Thesis. Istanbul Technical University Graduate School of Science, Engineering and Technology, Istanbul, Turkey.

Zakrys PI, Hogan SA, O’Sullivan MG, Allen P, Kerry JP. 2008. Effects of Oxygen Concentration on the Sensory Evaluation and Quality Indicators of Beef Muscle Packed Under Modified Atmosphere. Meat Sci, 79: 648655.doi:10.1016/j.meatsci.2007.10.030

Zakrys PI, O'Sullivan MG, Allen P Kerry JP. 2009.Consumer acceptability and physiochemical characteristics of modified atmosphere packed beef steaks. Meat Sci, 81720-725. doi:10.1016/j.meatsci.2008.10.024

Zakrys-Waliwander PI, O’Sullivan MG, Allen P, O’Neill EE, Kerry JP. 2010. Investigation of the Effects of Commercial Carcass Suspension (24 and $48 \mathrm{~h}$ ) on Meat Quality in High Oxygen Modified Atmosphere Packed Beef Steaks During Chill Storage. Food ResInt, 43: 277-284.doi:10.1016/j. foodres.2009.10.005. 